who died while he was administering chloroform to him, really died from its effects. Very few who have read the report of this case would have any doubts on the subject. To deny, at this advanced period of its history, and after more than fifty deaths caused by it have been published, that there is very considerable risk from chloroform, would be ridiculous, but still the advantage gained may overbalance this risk. Besides the insensibility produced by it, the assertion has been made, and the records of hospitals have been brought forward in support of the assertion, that amputation and other great operations are rendered safer by its use, in conseguence of the improvement which it causes in the condition of the patient. It is difficult to prove a matter of this kind by statistics, and a counter statement was made some years ago by one who had examined the records of operations, some performed with, and others without, chloroform, in the principal American hospitals. Nor is Dr. Snow's statement more satisfactory, that the pulse and general appearance of a patient who has taken chloroform manifests this improvement. A large quantity of brandy would for a time also give this appearance of improvement, (and probably from a similar or identical action on the system,) but would the ulterior conseguences of such stimulation be advantageous to the patient? I fear that there is detriment, and not advantage, from chloroform in this respect, and that we are not authorized, in making up the acconnt, to place lives only supposed to be saved in this manner against those that are certainly destroyed. W. Jules Guerin, in a report made to the Academy of Medicine in Paris, says "he believes that cases of death some time after, but in consequence of the exhibition of chloroform, are very numerous; and that in making inquiries of many surgeons, both in Paris and in the provinces, most of them have confessed that they had had occasion to regret the occurrence of these accidents." Still, in cases where the patient will not submit to deep-seated operations without perfect anesthesia, we are authorized to employ chloroform.

In those cases, however, where the same effect can be produced by local measures of perfect safety, it is unjustifiable to incur the hazard of life by the employment of chloroform. Here the argument, that the patient's condition is improved by it, (even admitting its soundness in other cases, hardly applies, for in small operations this is a consideration of comparatively little importance, and our duty is to perform these without any ansesthetic, or to employ one that is perfectly safe. To kill another patient by chloroform for the extraction of a toe-nail, for instance, (already there have been four deaths from this cause,) would now, as the public is fully aware of its danger, be considered culpable homicide.

In concluding these observations, I must express regret that greater care is not taken to enable us to form a correct judgment on this question, by the publication of the injurious effects of chloroform which happen in hospitals. In private practice this cannot be expected, and there is little doubt that few of such unfortmate events occurring privately are ever heard of. About a fortnight ago (January 13th) a medical periodical contained a list of the operations which had been performed, during three of the summer months, in certain provincial hospitals, and in this document a brief reference was made to a case of death from chloroform which had occurred in one of these hospitals more than three months before. The chloroform had been exhibited previously to an intended removal of a small encysted tumour from under the eyebrow; and but for what may be called the accidental publication of this list of operations, the death from etherization would probably never have been reported. As the question of the pro priety of exhibiting chloroform rests altogether on the question of the amount of danger incurred, it can never be properly settled unless more accurate knowledge is obtained of the facts from which we must reason.

I am, Sir, your most obedient servant,

London, January, $185 \overline{5}$. JAMES ARYOTT.

\section{THE ANATOMY OF THE NERVES OF THE UTERUS.}

[LETTER FROM DR. SNOW BECK.]

To the Elitor of THE LArceT.

SIR,-Without affording Dr. Robert Lee another opportunity to explain his conduct with regard to the lissection of the uterus, I am unwilling to adopt the conclusion which seems incritable from the facts of the case. I am aware that some time ago he sent a paper to the Royal society, wherein soveral. ganglia on the surface of the heart were lescribed; that he likewise presented drawings representing these ganglia, and appealed to his dissections for the accuracy of these statements. Yet when the dissections came to be examined, the whole was found to be an entire fabrication; for no such structures existed. I do not wish to conclude that the same wilful misrepresentation has been practised with reference to the ganglia of the uterus. For a period of more than fifteen years he has perseveringly urged this subject upon the attention of the profession; and however disagreeable it may be, I feel it now due to myself to gratify his apparent urgent desire for inquiry. Let it not therefore be supposed that silence on his part can stop this inquiry; for such silence will but carry the conviction, that like the ganglia on the heart, so are the re. puted ganglia of the uterus, a deception. I again call upon him to explain the following questions:-

(a.) Why the cellular tissue, or neurilemma, has been allowed to remain on the nerves in the dissections of the gravid uterus, figured in the "Philosophical Transactions," 1841-42, and in The Lancer, October 28th and December 9th, figures Nos. 1, 4 , and 5 ?

(b.) Why the cellular tissue, or neurilemma, has been re. moved in the dissections of the virgin uterus, figured in "Memoirs on the Ganglia and Nerves of the Uterus, by Dr. Robert Lee, 1849," and in THE LANCET, December 9th, figures Nos. 2 and 3 ?

(c.) Why the cellular tissue has been removed from the nerves in the dissection of the heart, figured in the "Philo. sophical Transactions" for 1849 , part i., plate 5 ?

(d.) Why the nerves of the gravid uterus surrounded by the cellular tissue, or neurilemma, have been compared with the nerves of the virgin uterus without the neurilemma?

(e.) Why the removal of the cellular tissue, or neurilemma, has been publicly condemned as a proceeding " altogether un. warranted and unprecedented," and yet has been secretly and surreptitiously removed in his recent dissections?

(f.) This will also afford Dr. Lee an opportunity to explain, What has become of the fifty ganglia described and represented on the nerves of the heart in May, 1847, with ${ }^{\circ}$ a Inxuriance of number and size;" yet when the preparations which were referred to as the basis of this communication came to be examined, "none of the fifty ganglia depicted could be discovered?"

February, 1855.
I am, Sir, your obedient servant,
T. SNow BECK.

\section{GIOVER VERSUS S Y ITE. To the Editor of THE LANCET.}

SrR,-I have this moment read, with peculiar pleasure, your pithy and admirable comment on the letter addressed to you by Mr. James Bell, and beg to express my cordial concurrence in all you have said. Mr. Syme has done good service to the medical profession in Scotland, by the manly stand he has made against a system which was absolutely intolerable; and whatever may be the feeling amongst lawyers, he has the almost unanimous gratitude of the profession throughout Scot. land, and, I doubt not, wherever the report of the trial is read. Mr. Syme is, fortunately for himself, not in a condition re quiring reimbursement for the heavy expenses he has incurred as the result of the verdict.

I may add that I have not seen Mr. Syme since the trial nor for long before it, and that I have no personcl interest whatever in the case that led to the trial; but that for his good deeds in this, as in many other professional matters, I avow myself,

Edinburgh, February, 185̃o. AN AmMnRer on Mr. Syme.

\section{COURT OF QUEEN'S BENCH}

THE QUEEN V. SMITH, THE REGISTRAR OF THE PHARILACEU. TICAL SOCIETY.

THIs was a special verdict found upon the trial of an issue raised upon a writ of mandamus to the Registrar of the Phar. macentical Society, commanding him to make and maintain a rerister of the members according to the provisions of the statute the 15 th and 16 th of Victoria, c. 56 . The question was whether the registrax was justified in registering as members persons who had been admitted as such, withont nndergoing examination, on the payment of certain fees for certiticates.

The case hal been argued some time since by Sir F. Kelly (with whom was Mr. H. Iloyd) on the part of the Crown; and by Mr. Bramwell, Q.C. (with whom was Mr. Brown) for the 